René Ariel Dotti, professor de direito penal na

Faculdade de Direito da Universidade Federal

\title{
O sursis e o livramento condicional nos projetos de reforma do sistema
}

\section{1 - Introdução}

\section{A crise das reações penais}

A fantástica crise das reações penais de feição clássica encontra o seu ponto de maior expressão no fracasso da pena segregadora, cujos contornos de tormento, por um lado, e alienação, por outro, plasmam a face negra da justiça criminal muito mais envilecida nos últimos tempos.

O Código penal brasileiro de 1940, considerado como um verdadeiro monumento jurídico na medida em que procurou consolidar as posições intermediárias das grandes escolas penais do final do século passado, dedica somente dois tipos de pena principal para combater a notável variedade de ilicitudes distribuídas no Código penal e leis extravagantes: a prisão e a multa. Cerca de 260 infrações sem contar as formas qualificadas e de especial diminuição penal - recebem todas elas no Código penal a cominação da pena privativa de liberdade, sendo a detenção em maior número. Em muitos casos a multa se aplica comulativamente e de maneira alternada em menor número de vezes. O procedimento de conversão da prisão pela multa é admitido em raras ocasiões (arts. 129, § 50; 155, § 20; 170; 171 , $\S 11^{\circ} ; 175, \S 2^{\circ}$ e e $180, \S 3^{\circ}$, por exemplo).

O caráter totalitário da pena de prisão, no seu estágio de execucão, constitui nos dias presentes a mais vigorosa crítica sofrida por uma instituição ao longo da história do direito penal em nosso país.

Os desvios e os abusos da pena segregadora têm determinado o seu descrédito como medida de terapia individual e de eficiente defesa da sociedade.
Também na lei das contravenções penais, o panorama da cominação massificadora do encarceramento é uma realidade. Para as 69 espécies de infrações ali descritas, a sanção privativa da liberdade é ameaçada 50 vezes, enquanto a multa é prevista com autonomia em 19 casos. Em 24 vezes ela é alternada e em 13 é cumulada com a chamada prisão simples. Diante de tal perspectiva, pode-se concluir que a perda da liberdade é ainda o instrumento jurídico incensado como o centro da gravidade do sistema.

\section{As formas de ilicitude e a proporcionalidade das penas}

A multiplicidade das formas de ilicitude com a vasta gama de peculiaridades materiais de antijuridicidade e distintas hipóteses de culpabilidade, recomenda maiores opções para a medida concreta da pena a fim de que não se comprometa violentamente a exigência da proporcionalidade como um dos seus mais importantes e humanos caracteres.

Paralelamente à crise das reações clássicas se manifestam as tendências de criminalização, neocriminalização, despenalização e destipificação com todo o cortejo de problemas que estimula o debate e fecunda novas possibilidades de interação entre a justiça criminal e a condição humana dos personagens responsáveis pela vida e pela morte que transcendem a temporalidade do fato.

Os meios de comunicação de massa, especialmente a televisão, tem contribuído decisivamente para que o homem contemporâneo sofra a experiên- 
çia da angústia e o terror do medo, quando transmitem com a velocidade do som e da imagem, as dores do mundo e o espectro da violência. Esse fenômeno vem gerando a impaciência coletiva com graves riscos para a segurança individual e social, quando o impacto dos eventos delituosos é bem ampliado pelos detalhes de exposição e pela síndrome das reações violentas. O quadro da universalização da notícia faz com que um crime cometido em outro continente repercuta na mais pacata cidade do Nordeste ou do Sul brasileiros, aumentando o sentimento de insegurança, posto que normalmente é o delito e não a aplicação da pena que estimula o sensacionalismo dos meios de comunicação. ${ }^{2}$

As conexões existentes entre o estímulo à violência através dos meios de informação e a desproporcionalidade nas reações penais são facilmente demonstráveis. Ao lado de outros fatores como a neurotização da vida urbana em centros populacionais muito adensados, as grandes migrações internas e a má distribuição de rendas, a propaganda da força para combater o crime incentiva não somente as classes sociais ao exercício da 'justiça pelas próprias mãos' como também os agentes do poder público à prática do abuso de autoridade. O quadro assim composto poderá gerar uma legislação de pânico com gravíssimas conseqüências para a segurança jurídica. A proporcionalidade entre o crime e a punicão em tal circunstância deixa de ser mero 'caráter' da pena para ser reconhecida como verdadeiro 'princípio de eqüidade' a imitar a máxima religiosa segundo a qual o castigo não pode ser maior que o pecado.

\section{A pena de morte e a angústia de Abraão}

Em muitas situações, a omissão do Estado em prevenir e reprimir adequadamente os vários tipos de ofensa estimula a formação de expedições punitivas que se encarregam do justiçamento sumário de supostos delinqüentes, particularmente no campo dos furtos de bagatela quando o linchamento é a resposta cruel contra o punguista e outros pequenos tipos de ladrão.

A pena de morte, em tais circunstâncias, passa a ser cogitada pela sociedade ofendida, como remédio pronto e eficaz para debater a violência e a criminalidade. No entanto, para o legislador e para o juiz a imposição da pena capital implica em nova forma de suplício espiritual assim como o descreveu Kierkegaard chamando-o de a 'angústia de Abraão', assim resumida por Sartre: "um anjo ordenou a Abraão que sacrificasse o filho. Está tudo certo, se foi realmente um anjo que apareceu e disse: tu és Abraão, tu sacrificarás o teu filho. Mas cada qual po- de perguntar-se, antes de mais: trata-se realmente de um anjo, e sou eu realmente Abraão? Quem é que afinal mo prova?"3

\section{II - As alternativas para a pena de prisão}

\section{Compreensão do tema}

Em nosso entendimento, as alternativas para o sistema de sanções constituem meios, métodos e formas de reação do delito que devem atuar em todos os momentos do dinamismo penal. Através da cominação, quando o ordenamento positivo consagra novas modalidades de sanção; da aplicação, quando ao juiz se possibilitam condições para a melhor escolha e medição da pena; e da execução, quando os regimes dispõem de condições formais e materiais que atendam aos objetivos das medidas de prevenção e repressão da criminalidade.

Mas não se trata de um simples processo de 'substituição' assim como se mudasse o curso do sistema abolindo algumas penas e introduzindo outras sem que a esse fenômeno se apresentassem as justificativas necessárias. Alternar não é somente a 'escolha' como também - e principalmente - um 'procedimento racional' de escolha. ${ }^{4}$

Existem alternativas para a pena de prisão (multa, sursis, etc.) e também alternativas na pena de prisão - instituições de regimes fechados, semiaberto e aberto, e as permissões de saída, por exemplo - que têm a finalidade de reduzir a massificação ou atenuar os seus notórios inconvenientes quando a execução se processa em meio fechado.

Os regimes de execução e as permissões de saída, consagrados através da reforma introduzida pela lei n. 6.416 de 24 de maio de 1977, constituem alternativas para limitar os males da 'execução contínua' da pena de prisão, classicamente considerada como segregação total.

\section{As reações não institucionais}

Ao lado da reclusão, da detenção e da prisão simples, são também medidas institucionais o internamento em manicômio judiciário, em casa de custódia e tratamento, em colônia agrícola ou em instituto de trabalho, de reeducação ou de ensino profissional (Código penal, arts. 28, 29, 88 § 1. e LCP, art. $\left.5^{\circ}, 1\right)$.

As reações de fundo não institucional como a multa e as chamadas penas acessórias (perda de função pública, interdição de direitos e publicação de sentença condenatória - Código penal, arts. 28 , III; 35 e 67) não se integram adequadamente num 
sistema lógico, moderno e que atenda efetivamente aos interesses da sociedade, aos direitos e às garantias individuais. ${ }^{5}$

O Anteprojeto de reforma da parte geral do Código penal $(1981)^{6}$ extinguiu a categoria das penas acessórias e, conseqüentemente, a divisão geral das penas em principais e acessórias para declarar que as formas de reação se classificam em privativas de liberdade, restritivas de direitos e patrimoniais (art. 32).

As penas restritivas de direitos consistem na prestação de serviços à comunidade, na interdição temporária de direitos e no aprendizado compulsório (art. 43). Esta última modalidade realiza-se pela freqüência a curso ou ciclo de palestra no qual o condenado por crime culposo viesse a adquirir conhecimentos necessários para evitar a ocorrência de novas infraç̃es e a estimular o dever social de cuidado.

Nos trabalhos de revisão do Anteprojeto ${ }^{7}$ o aprendizado compulsório foi substituído pela medida a que se denominou de limitação de fim de semana. O condenado é obrigado a permanecer, aos sábados e domingos, por cinco horas diárias, em casa do albergado ou outro estabelecimento adequado, participando de cursos e assistindo palestras ou, ainda, ter a si atribuídas atividades educativas (arts. 43, III e 48 e parágrafo único).

As penas restritivas de direitos consagrados no Anteprojeto constituem as vertentes para um fecundo processo de mobilização das reações não institucionais, libertando o juiz do imobilismo a que está condenado quando o ordenamento positivo somente the oferece as opções extremadas da prisão e da liberdade (com multa) para atender a vasta gama de ilicitude com todos os seus peculiares matizes e as suas caleidoscópicas formas. Na correta observação de Miguel Reale Júnior, "as penas restritivas constituem indispensáveis condições de possibilidade da Justiça Penal, outorgando ao monolítico direito penal, virtualidades que apenas o dignificam dotando a sanção do inafastável cunho retributivo, sem descuidar de estar viabilizando a melhoria da pessoa do condenado" 8

Sob um outro aspecto, as reações não institucionais (as penas restritivas de direitos, a multa e a própria prisão-albergue como hipótese do regime aberto e como sanção autônoma) caracterizam propostas concretas para que a justiça criminal seja meIhor atendida frente às exigências de segurança e paz de uma sociedade que se transforma e resiste aos arquétipos tradicionais da repressão.

No recentíssimo Código penal português (decreto-lei n: 400/82) a liberdade do juiz para a escoIha e a medida da pena é criteriosamente estabelecida pelo art. 71.: "Se ao crime forem aplicáveis pe- na privativa ou dena nãop pivativa de liberdade, deve o tribunal dar preferência fundamentada à segunda sempre que ela se mostre suficiente para promover a recuperação social do delinqüente e satisfaça as exigências de reprovação e de prevenção do crime".

A inovadora regra tem profundas implicações teóricas e práticas, além da virtude de romper o quietismo compreendido pela filosofia sartreana como a atitude das pessoas que dizem: "os outros podem fazer aquilo que eu não posso fazer". 9

\section{III - A suspensão condicional 6. Natureza jurídica}

Impropriamente tratado como incidente da execução na letra do Código de processo penal CPP (arts. 696 e ss.) o sursis tem sido visto pelos escrtitores italianos como a debolezze della repressione na medida em que contribui para o descrédito da instituição sob os aspectos da proporcionalidade e da intimidação além de se ter convertido, na prática penal, em 'garantia' sistemática de impunidade para o primeiro delito. ${ }^{10}$

Dentro desse contexto de crítica e revisão coloca-se o projeto de Código penal espanhol (1980) ao restringir as hipóteses de concessão do sursis em favor do réu primário e que não tenha sido revel, impondo também como requisitos: que a infração praticada não seja grave; que o condenado seja menor de 21 anos ao tempo do fato. Excepcionalmente se concederá a medida aos maiores de tal idade, quando o infrator não tenha atuado por motivo abjeto ou de lucro, demonstre arrependido ou regeneração e a pena imposta não for excedente a um ano de privação de liberdade, dias-multa que não sejam inferiores a seis meses ou prisão de fim de semana (art. 92).

Essa perspectiva de crise põe à mostra a primeira dificuldade, de natureza teórica, para a compreensão do instituto. Com efeito, a suspensão condicional da pena é um mero incidente de execução ou deve ser tratada como verdadeira medida penal de caráter restritivo da liberdade?

Na tradição do direito brasileiro, o sursis é considerado como um benefício ao infrator primário, atendidos determinados requisitos e cumpridas algumas condições.

Uma antiga doutrina, porém, já oferecia base suficiente para se defender a idéia de que a chamada 'condenação condicional' reunia caracteres próprios de pena, mesmo sendo tratada como um favor. Em tal sentido orientou-se a dissertação apresentada por José Mendes, no ano de 1908, em concurso prestado na Faculdade de Direito de São Pau- 
lo. Respondendo às objeções lançadas contra o instituto - entre elas a de que com sua aplicação se violava o princípio de justiça segundo o qual a cada crime deveria corresponder uma pena - dizia ele que: "A própria condenação condicional é uma pena consistente na ameaça feita ao delinqüente; é um substitutivo penal, que não perde a natureza de pena. É pena no verdadeiro sentido, o científico. É pena adequada ao nosso tempo". E confrontando as doutrinas sintetizadas pelas duas grandes escolas penais, arrematava: "Pena - segundo o conceito clássico, é o mal que se padece por causa do mal que se fez - malum passionis quod infligitur ob malum actionis. Ao passo que, no conceito da escola penal positiva, fundada por Lombroso, Ferri e Garofalo, pena - é o conjunto dos meios jurídicos empregados pela sociedade na luta contra o crime. O instituto da condenação condicional, inspirado nos ensinamentos da nova escola, pressupõe esse conceito de pena, ao passo que a objeção, inspirada pelas teorias absolutas do direito de punir, pressupõe aquele outro conceito de pena. Dai a divergência, que se explica pelo atraso dos impugnadores do instituto."11

No regime do Código de 1940 com as reformas introduzidas, tal medida é prevista no capítulo III (arts. 57 e ss.) do título V, que trata das penas. A sua colocação sistemática, após o capítulo referente à aplicação da pena, conduz ao entendimento de que a natureza jurídica do sursis é compreendida como a modificação do regime de execução da pena privativa de liberdade.

Aníbal Bruno ensina que a suspensão condicional da pena "é o ato pelo qual o juiz, condenando o delinqüente primário não perigoso a pena de tentativa de curta duração, suspende a execução da mesma ficando o sentenciado em liberdade, sob determinadas condições. "12

Mas o caráter tipicamente penal da medida é antevisto pelo prestigiado mestre quando, ao falar sobre a principal vantagem do sistema belga-francês que adotamos, salienta a intimidação resultante da eventualidade em se executar a pena privativa de liberdade imposta. Com isso "se exerce sobre o ânimo do condenado uma impressão intimidativa, reforçada pela ameaça do cumprimento de uma pena certa, que passa a pesar sobre ele e que se efetivará se ele faltar aos seus deveres."13

Outros aspectos levam à convicção de que o sursis é uma autêntica medida penal de fundo não institucional. Basta atentarmos para as necessidades da individualização lque é uma das garantias individuais consagradas pela Constituição na aplicação da pena) e da proporcionalidade. Estas duas exigências estruturais da pena moderna foram especialmente reforçadas com a redação do parágrafo $1^{\circ}$. do artigo 698 do Código de processo penal - CPP, em conseqüência da reforma introduzida pela lei $n$. $6.416 / 77$. Diz o aludido dispositivo que as condições para a suspensão serão adequadas ao delito e à personalidade do condenado.

A jurisprudência tem consagrado a orientação de que o arbítrio judicial para a escolha e aplicação constitui verdadeiro ato vinculado. Assim, por exemplo, reconheceu-se inadmissível a obrigação de reparar o dano, imposto ao condenado por incêndio culposo (RT 450/417); a proibição de freqüentar, auxiliar ou desenvolver cultos religiosos em locais que não sejam especificamente destinados a esse fim foi declarada inconstitucional pelo Supremo Tribunal Federal. No mesmo precedente, decidiu-se que é humilhante a condição imposta à 'beneficiária' (punida a sete meses de detenção por crime de maus tratos aos filhos menores) de carregar pessoalmente, à cadeia pública local, determinadas latas d'água por mês (RT 552/431). Num caso de sedução, o Tribunal de Justiça de São Paulo reconheceu ser desproporcionada a condição de dotar a ofendida através de quantia compatível com o seu estado social "se se trata de operário, ganhando modesto salário" (RT 510/332). Igualmente não se admite a determinação para reparar o dano, posto tratar-se de matéria especificamente regulada no Código Civil (RT 534/379).

A natureza jurídico-penal do sursis foi posta com 'clareza de sol mediterrâneo' por Jescheck, após referir que o aludido instituto constitui a parte mais importante da reforma político-criminal empreendida após a II Guerra Mundial. Conceitualmente a suspensão é um "medio autónomo de reacción jurídico-penal que tiene varias posibilidades de eficacia. Es pena, en tanto que se condena a una pena privativa de liberdad y el condenado tiene antecedentes penales". Além dessa característica, revela ser um 'meio de correção' e também 'medida de ajuda social' e finalmente revela um aspecto sóciopedagógico ativo ao estimular o condenado para que ele mesmo, com suas próprias forças, possa reintegrar-se na sociedade. ${ }^{4}$

O sentido sancionatório do sursis é admitido por outros autores. Para Bruns é um 'nova sanção autônoma'; segundo Jagusch tem ele a 'natureza de pena autônoma'; enquanto que Geerds admite ser uma 'forma de sanção totalmente autônoma'. Welzel reconhece ser o instituto em exame 'um meio penal de especial natureza'. ${ }^{15}$

A sentença condicional foi expressamente relacionada entre as penas principais no Projeto Eduardo Correia (1963) ao lado da prisão, da multa e do regime de prova (art. $47^{\circ}$ ).

No regime do atual Código penal português, 
as penas principais são a prisão e a multa. Mas a suspensão da execução, a probation, a admoestação, a prestação de trabalho a favor da comunidade e a liberdade condicional (arts. $48^{\circ}$ e e ss.) são tipicamente tratadas como substitutivos à privação da liberdade. Não porém como "mera subtituição automática da prisão. Como reações penais de conteúdo pedagógico e reeducativo (particularmente no que diz respeito ao regime de prova), só devem ser decretadas quando o tribunal concluir, em face da personalidade do agente, das condições de sua vida e outras circunstâncias indicadas no artigo $48^{\circ}$, n. 2 (aplicável também ao regime de prova por força do artigo 53.) serem essas medidas adequadas a afastar o delinqüente da criminalidade." 16

O tema relativo à natureza jurídica do sursis caracteriza um dos problemas em aberto para os penalistas. A opinião dominante reconhece na suspensão mediante condiç̃es somente uma 'modificação da execução da pena', ou então uma 'medida de correção'. Schmidhäuser sustenta tratar-se de uma forma de "impunidade privisória relacionada com conseqüências jurídico-penais não retributivas de peculiar natureza."17

Em nosso entendimento e diante do ordenamento positivo brasileiro, o sursis é uma autệntica medida penal de natureza sancionatória e com as características próprias de pena - legalidade, personalidade, proporcionalidade e humanidade.

E não obstante ser considerado como um direito público subjetivo do réu ${ }^{18}$, não deve se desprender das exigências da retribuição e da prevenção especial, conciliando-se as idéias de punição, de correção pessoal e de interesse comunitário principalmente quando as condições beneficiam um indeterminado número de pessoas (prestação de trabalhos etc.)

\section{A evolução legislativa}

O desenvclvimento do instituto do sursis durante a vigência do Código penal de 1940 e os documentos legislativos posteriores revelam a tendência crescente de adaptação dos postulados fundamentais de um sistema que melhor atende aos interesses individuais e coletivos.

O artigo 57 do Código penal, em sua primitiva redação, vedava a medida para os condenados à reclusão, salvo quando se tratasse de autor menor de 21 anos ou maior de 70 . A restrição foi mantida pelo Código de 1969 (decreto-lei n? 1.004 de 21 de outubro de 1969, art. 71).

Com a reforma introduzida pela lei n: 6.016 de 31 de dezembro de 1973, a suspensão condicional passaria a alcançar, indistintamente, os sentencia- dos a qualquer das penas privativas de liberdade (art. 70). Diante da adoção do critério da periculosidade como fundamento para a medição concreta da pena e visando orientar a sua execução (art. 52 e § 1.9) foram instituídas duas modalidades de suspensão condicional: 1.) simples, ao condenado de nenhuma periculosidade; $2^{\text {a) }}$ mediante regime de prova, ao condenado de escassa periculosidade; a este se imporiam obrigações e proibiç̃̃es cujo cumprimento seria fiscalizado "quando possível, por pessoal especializado" (arts. 70, § 10 e 71).

A novidade pretendia consagrar a experiência já vitoriosa em outros países que implantaram o regime da probation. Continha, porém, um vicio de origem ao não introduzir legalmente a figura do agente da probation, a exemplo de outros sistemas que não admitem a fiscalização por pessoas que não estejam afeitas a essa modalidade de trabalho social. $^{18}$

Muito vagamente o Código penal de 1969 estabelecia, como um dos requisitos da concessão, o fato de não ter o réu sofrido condenação anterior por crime ou contravenção 'reveladora de má índole' (art. 71, I) e acrescia ao exame dos antecedentes e da personalidade do sentenciado, dos motivos e das circunstâncias do crime (como ocorria no regime do Código de 1940), a verificação da conduta posterior do delito "indicativa de arrependimento ou do sincero desejo de reparação do dano" para se aferir a presunção de que o condenado não tornaria a deliqüir (art. 71, II).

Embora não impondo como requisito formal a indicação de arrependimento, a reforma decorrente da lei n. 6.016/73 mantinha a exigência da demonstração do "sincero desejo de reparar o dano" (art. 70).

Contudo, foi com o advento da lei n. $6.416 / 77$ que o instituto sofreu as maiores e melhores correções. Em lugar da primariedade absoluta, admitiuse que o sursis seria aplicado ${ }^{20}$ também quando entre a data do cumprimento ou extinção da pena e a infração posterior houvesse decorrido o tempo superior a cinco anos (temporariamente da reincidência, conforme o parágrafo único do art. 46)

Acolhendo a súmula n. 499, a reforma dispôs que a condenação anterior à pena de multa não constituiria mais obstáculo à determinação da medida. Tal conclusão infere-se da leitura do novo artigo 57 ao impor, como requisito, a ausência de "condenação irrecorrivel por outro crime a pena privativa de liberdade". A condenação anterior por contravenção também não veda o funcionamento do sursis.

Outras inovações merecem destaques: 1. a proporcionalidade e a individualização das condi- 
ções que devem ser "adequadas ao delito e à personalidade do condenado" (Código de processo penal - CPP, art. 698 § 1․); $2^{\text {a }}$ - a previsão legal das condições (liberdade vigiada, freqüência a curso de habilitação profissional ou de instrução escolar, prestação de serviços à comunidade, atendimento dos encargos de família, submissão a tratamento de desintoxicação) (Código de processo penal - CPP art., 698 § 2.). Fica em aberto a possibilidade de fixação de outras condições, além das especificadas na sentença e no texto legal referido, "desde que as circunstâncias o aconselhem" (Código de processo penal - CPP, art.698 § 3.); $3^{a}{ }^{a}$ - a exigência de que a fiscalização do cumprimento das condições deve ser regulada nos estados, territórios e Distrito Federal por normas supletivas e atribuída a serviço social penitenciário, patronato, conselho da comunidade ou entidades similares, inspecionadas pelo conselho penitenciário, pelo ministério público ou ambos (Código de processo penal - CPP, art. 698 § 4.); 4. - a redução das hipóteses de revogação obrigatória e facultativa (Código penal, art. 59 , § 1.). 21

\section{O sursis nos projetos atuais de reforma}

O Anteprojeto de reforma da parte geral do Código penal trouxe profundas modificações.

0 artigo 77 estabelece que a execução da pena privativa de liberdade não superior a dois anos poderá ser suspensa nos crimes cuja pena máxima seja superior a três anos. Quando a sanção cominada for inferior ao aludido quantum - homicídio culposo, lesões corporais leves, alguns delitos de periclitação da vida e da saúde, a rixa, os crimes contra a honra etc. - , o juiz aplica uma pena restritiva de direitos (arts. 43, 44, 45 e 56).

Estabeleceu-se, de inicio, uma distinção muito clara entre os casos de suspensão de execução da pena privativa de liberdade (para as situações de maior gravidade) e substituição da prisão pelas sanções referentes à prestação de serviços à comunidade, interdição temporária de direitos e o aprendizado compulsório (esta última modalidade cedeu lugar à limitação de fim de semana, como já se viu).

Diante do novo sistema proposto, o juiz passaria a dispor de maiores opções para decidir sobre a medida penal concreta a uma variedade muito freqüente de ilicitudes, sem a rotineira e monótona 'concessão sistemática' do sursis estabelecendo os mesmos e gastos repertórios de condiç̃es cuja generalização envolve tanto a lesão corporal como a injúria, a rixa e a ameaça ou a violação de domicílio etc.

Na revisão do Anteprojeto, a redação do ca- put do artigo 77 foi modificada para declarar-se que "a execução da pena privativa de liberdade, não superior a dois anos, poderá ser suspensa, por dois a quatro anos, desde que..." Em conseqüência, todos os delitos independentemente do máximo da pena cominada poderão, em princípio, admitir a suspensão condicional. No entanto, o juiz deve examinar, em cada caso concreto, a possibilidade de aplicar uma pena restritiva de direitos desde que cabivel e indicada (art. 77, III). E o artigo 44 dispõe que as penas restritivas de direitos não autônomas substituem as privativas de liberdade quando: I - for imposta pena de prisão inferior a um ano ou mesmo superior se o delito for culposo; II - o réu não for reincidente; III - a culpabilidade, os antecedentes, a conduta social e a personalidade do condenado, bem como os motivos e as circunstâncias, indicarem que essa substituição seja suficiente.

Muito embora o texto do Anteprojeto revisto ainda se refira ao sursis como um benefício, ${ }^{22}$ os requisitos para a sua aplicação e outros aspectos autorizam a interpretação de que, na verdade, o instituto passa a ser considerado e tratado como sanção penal de natureza peculiar. Assim, pode-se referir ao disposto no inciso II do artigo 77 declarando que, para suspender a execução da pena de prisão, o juiz deve ter em linha de consideração a medida da culpabilidade lalém dos antecedentes, da conduta social e da personalidade do autor, bem como dos motivos e das circunstâncias do delito).

Eliminou-se, conseqüentemente, o genérico requisito relativo a "presunção de que (o sentenciado) não tornará a delinqüir" (Código pena/57, II). No sistema proposto, aboliu-se expressamente o critério deambulante e fluido decorrente das presunções para se declarar que o sursis é aplicável quando o exame da culpabilidade, e dos demais requisitos acima enunciados, indique ser a medida 'necessária e suficiente'. A solução adotada é um corolário lógico da erradicação da presunção de periculosidade que não mais se admite no Anteprojeto.

Por necessidade deve-se compreender o sentido de reprovação que também envolve o instituto; e por suficiência deve-se entender a satisfação das exigências de prevenção tanto geral como especial. Estes dois aspectos revelam nitidamente a preocupação do Anteprojeto em fundamentar a medida de suspensão à luz dos princípios da proporcionalidade, da personalidade e da humanidade.

Também como importantes modificações devem ser realçadas: $1^{\text {a }}$ ) a redução do período de prova para o tempo de 2 a 4 anos (e não mais de 2 a 6 anos), 2. ) ao condenado à pena privativa de liberdade por crime culposo é possível o sursis; $3^{\text {a }}$ ) também ao reincidente em crime doloso poderá ser im- 
posta a medida desde que a condenação anterior seja a pena de multa; 4. ) a sujeição do condenado à observação durante o prazo da suspensão; 5. ) a imposição obrigatória, durante o primeiro ano do praZo, das medidas de prestação de serviços à comunidade ou da limitação de fim de semana; 6 .) a substituição das sanções acima indicadas pelas condições de: a) proibição de freqüência a determinados lugares; b) proibição de ausentar-se da comarca da residência salvo autorização judicial; c) comparecimento pessoal e obrigatório a juízo, mensalmente, para informar e justificar as suas atividades desde que o condenado tenha reparado o dano, salvo impossibilidade de fazê-lo e as circunstâncias judiciais da aplicação da pena the sejam favoráveis (art. 77 e ss.).

As características marcadamente sancionatórias do sursis defluem igualmente das modificações referidas nas quais se percebe o propósito de adequar ainda mais o instituto às exigências da proporcionalidade e da personalidade da pena quando: a) reduz o período de prova remediando flagrantes injustiças materiais, como o prazo por tempo superior ao máximo da pena de prisão cominada em prejuízo da reabilitação; b) trata diversamente os responsáveis por delito doloso e os infratores por delito culposo; c) distingue entre o condenado à pena privativa de liberdade e o condenado à pena de multa; d) a observação do condenado corresponde à necessidade de se individualizar a execução. Assim, já se pretende com o recluso, no período inicial de cumprimento da pena privativa de liberdade (Código penal, art. 30) demonstrando similitude entre as providências e seus objetivos; e) tanto a prestação de serviços à comunidade como a limitação de fim de semana são penas propriamente ditas na proposta do Anteprojeto. A sua aplicação obrigatória revela que para muito além de simples e não raro vagas e inadequadas 'condições', as referidas providências estruturam a base retributiva e também os fins preventivos que existem na suspensão conforme o sistema agora proposto; f) por último, a substituição das sanções restritivas por normas de conduta vem revelar a diferença entre umas e outrăs, ou seja entre penas, como tais declaradas e condições.

O Anteprojeto revisto da Lei de Execução Penal (1981)23 inclui a suspensão condicional sob a rubrica do título $\mathrm{V}$ que trata da 'execução das penas em espécie', contendo os seguintes capítulos: I Das penas privativas de liberdade; II - Das penas restritivas de direitos; III - Da suspensão condicional; e IV - Da pena de multa.

$\mathrm{O}$ instituto assim distribuído não é mais considerado como um mero incidente de execução. E o conteúdo penal stricto sensu é também enfatizado no Anteprojeto da Lei de Execução Penal quan- do o seu artigo 159 estabelece a necessidade da audiência de leitura da sentença condenatória pelo próprio juiz que advertirá o sentenciado das conseqüências de uma nova infração e do descumprimento das condições (rectius: medidas) impostas.

Trata-se da consagração legislativa da pena de admoestação considerada como eficiente reação de fundo moral e que se presta para combater certas formas de criminalidade menos grave e praticadas por determinados tipos de autores: lesões corporais simples; ilicitos contra a honra, ameaça, receptação culposa, etc., quando os agentes forem primários, de boa conduta e revelarem sensibilidade para sofrer a reprovação e a intimidação resultantes do ato solene de advertência sobre as conseqüências de uma nova infração.

A admoestação já está integrada no Código penal espanho/ pelas formas de repreensão pública e repreensão privada (art. 89) e nos códigos russo (art. 22), alemão (§ 59) e muito apropriadamente no atual português (art. 59\%).

Entre os escritores que defendem a eficácia da admoestação, pode-se incluir José M. Rico, que a compreende como adequada aos infratores providos de um alto sentido da própria dignidade. ${ }^{24}$

\section{IV - O livramento condicional 9. Natureza jurídica}

A liberdade do réu que está cumprindo pena privativa de liberdade mediante o cumprimento de certas restrições e deveres constitui, também, uma das mais oportunas modalidades de alternativas para eliminar os incovenientes resultantes do lado físico do mal da pena.

Entre os escritores brasileiros, Basileu Garcia considera o livramento condicional uma 'medida de política criminal', aparecendo como uma das "providências inteligentemente concebidas no sentido de se conseguir cada vez mais, na prática, a relativa indeterminação da sentença criminal" 25 Outros penalistas como Jescheck lembram que a instituição é também chamada de suspensão do resto da pena. ${ }^{26}$ E para Aníbal Bruno, tendo em linha de consideração o sistema brasileiro, o livramento condicional é "medida de política criminal que se inspira na idéia da prevenção do crime pela emenda do criminoso". Negando tratar-se de simples libertação antecipada, o eminente penalista concebe o instituto como um "estágio do sistema penitenciário que importa na progressiva adaptação do condenado a uma existência dentro do direito e termina, por esse momento de passagem entre a prisão e a liberdade" 27

Assim como nos manifestamos em relação ao 
sursis, entendemos que o livramento condicional também deve ser considerado como uma reação penal de natureza peculiar com características tipicamente sancionatórias consistentes na restrição da liberdade e na satisfação de encargos e condições. Como alternativa à prisão - continuação do cumprimento da pena privativa de liberdade - o sistema abre ao juiz a oportunidade para considerar desnecessário (e, conseqüentemente, desproporcionado) o sofrimento do cárcere, posto que através da liberdade mediante condições se perseguem os objetivos de reprovação, prevenção e recuperação social do condenado.

A caracterização do instituto como reação penal de fundo não institucional harmoniza-se com os conceitos atrás referidos, posto que, como providência sancionatória não deixa de constituir, também, medida de política criminal. Como, aliás, é de política criminal a substituição da pena privativa de liberdade pela de multa.

\section{A evolução legislativa}

Um dos graves inconvenientes do instituto durante o longo período de 35 anos foi a limitação estabelecida pelo Código de 1940 que, na redação original do artigo 60, dispunha como requisito para o livramento condicional a quantidade de pena de reclusão ou de detenção superior a três anos. Com tal critério, o sistema abria um hiato profundamente injusto quando se condenavam le com que freqüência) réus a uma pena superior a dois porém inferior a três anos. Ficava o sentenciado à margem de lhe ser aplicado o sursis e o livramento condicional. Criava-se, por outro lado, o paradoxo segundo o qual o condenado a uma pena superior a três anos (três anos e um dia como se constatava, também com freqüência) estava em melhor situação que o sentenciado à pena de dois anos e seis meses, por exemplo, diante da possibilidade do livramento condicional. O absurdo de tal disparidade era responsável também pelos pedidos de revisão criminal nos quais se pleiteava o aumento da pena a fim de permitir o livramento antecipado (!).

O Código de 1969, porém, corrigiu aquele defeito para permitir a liberação condicional ao condenado à pena de reclusão ou de detenção por tempo igual ou superior a dois anos (art. 75்).

No confronto entre os textos do Código de 1940 e diplomas posteriores, podem ser encontrados pontos de reforma bastante importantes, como: a) diminuição do tempo de cumprimento parcial da pena; b) a redução de um terço do prazo de cumprimento da pena quando o condenado fosse primário e menor de 21 anos ao tempo do fato ou maior
70 ao tempo da sentença; c) a determinação de que - liberado ficaria sob observação cautelar e proteção realizadas por patronato oficial ou particular e, na falta, a observação seria promovida por serviço social penitenciário ou órgão similar; d) a revogação obrigatória somente se operaria se o liberado viesse a ser condenado irrecorrivelmente à pena privativa de liberdade e não a qualquer outra.

Sob o advento da lei n. 6.416/77 o livramento condicional foi aperfeiçoado em muitos aspectos. Primeiramente, passou a ser aplicado em caso de pena privativa de liberdade igual ou superior a dois anos (art. 60), permitindo-se, também, a soma das penas correspondentes a infrações diversas para possibilitar a medida. E a exemplo do ocorrente com a suspensão condicional, foram modificadas as causas de revogação, tanto obrigatórias como facultativas, conforme as situações que foram assim resumidas por Rogério Lauria Tucci: a) sendo a condenação irrecorrivel e por crime anterior ou contemporâneo à vigência da medida, será causa obrigatória da revogação a imposição de pena privativa da liberdade (Código de processo penal - CPP, art. 726); b) será causa facultativa da revogação a condenação irrecorrível a pena pecuniária (Código de processo penal - CPP, art. 727); c) também será facultativa a causa de revogação quando houver inobservância das obrigações constantes da sentença ou inerentes à pena acessória (Código de processo penal CPP, art. 727).28

Constituiu também importante inovação a possibilidade do juiz alterar as condições ou normas de conduta especificadas na sentença. A leitura da decisão ao liberado em audiência formal (Código de processo penal - CPP, art. 731) assume características de solenidade compatível com o sentido tanto de reprovação como de prevenção do delito.

\section{O livramento condicional nos pro- jetos atuais de reforma}

O Anteprojeto revisto limitou sensivelmente os prazos de cumprimento parcial da condenação. O condenado de bons antecedentes, primário ou mesmo quando reincidente por ter anteriormente cometido um ilícito culposo, poderá ser liberado após o cumprimento de um terço da pena. Já o reinciden. te doloso terá de cumprir mais da metade lart. 83, I e II).

Uma das inovações importantíssimas residiu em se suprimir o pressuposto da ausência ou cessação de periculosidade (Código penal, art. 60, II). Diante da orientação em se abandonar o sistema do duplo binário e a presunção normativa de periculosidade, o Anteprojeto, dispôs que é também requisito para o livramento a comprovação da conduta 
satisfatória durante a execução da pena o bom desempenho no trabalho atribuído e a aptidão para prover a própria subsistência mediante trabalho honesto (art. 83, III).

Revelando suas apreensões em torno do grave problema da criminalidade violenta, que assume conformação de pânico nos grandes centros urbanos afetados pelas agressões ao patrimônio, o Anteprojeto dispõe que: "Para o condenado por crime doloso, cometido com violência ou grave ameaça à pessoa, a concessão do livramento ficará também subordinada à verificação, em perícia, da superação das circunstâncias que o levaram a delinqüir" (parágrafo único, art. 83).

Não se cogita, aqui, de uma investigação referente à periculosidade como um prognóstico, um juízo sobre o futuro, mas de uma análise sobre o passado a fim de se deduzir, com elementos concretos extraídos do levantamento da personalidade da conduta do condenado e das circunstâncias externas (meio ambiente - qualidade de vida, etc.) ou internas (estado mental e psicológico). A 'superação das circunstâncias' a que alude o Anteprojeto consiste na modificação do quadro em que o sentenciado estava inserido, tanto sob o ângulo familiar como social, na casa ou na rua.

A perícia necessária à verificação do estado atual do condenado deverá ser procedida por uma comissão que nos termos do Anteprojeto da Lei de Execução Penal está prevista para cada estabelecimento, sendo presidida pelo diretor e composta, no míinmo, por dois chefes de serviço, um psiquiatra, um psicólogo e um assistente social. Esta comissão técnica de classificação é responsável pela elaboração de um programa de individualização e acompanhará a execução das penas privativas de liberdade e restritivas de direitos, devendo propor, à autoridade competente, as progressões e regressões dos regimes bem como as suas conversões (art. 6. e 7.\%).

No relatório dos trabalhos da Comissão Parlamentar do Inquérito destinada a proceder ao levantamento da situação penitenciária do país, já foi salientado que as mutações de comportamento do condenado ocorridas no curso da execução devem ser acompanhadas por juntas de observação em efetiva e permanente atividade nas penitenciárias. Naquela oportunidade ponderou-se que as juntas, responsáveis pelo exame inicial da personalidade e pela assistência ao condenado no curso da execução, serão integradas por psicólogos, psiquiatras, criminólogos e assistentes sociais, dentre outros especialistas. 29

O exame médico-psicológico e social dos delinqüentes é a base da criminologia clínica e os métodos utilizados variam não somente conforme a na- tureza (social, médica, psiquiátrica e psicológica) como também pela profundidade que podem alcançar, conforme bem esclarece Pinatel. ${ }^{30}$

O livramento condicional no sistema proposto pelo Anteprojeto revisto da Lei de Execução Penal deixa de ser um mero incidente de execução da pena $^{31}$ para receber o tratamento de uma efetiva reação penal de fundo não institucional. Dai porque a sua colocação na seção $\mathrm{V}$ do capítulo I que trata da execução das penas privativas de liberdade.

Dentro dessa perspectiva, o instituto assume importante posição no repertório geral das alternativas à prisão, ao mesmo tempo em que se caracteriza por um conjunto de medidas que o libertam do quadro monótono e caótico atual, quando as distâncias entre o juizo da execução, o conselho penitenciário, os peritos e a administração penitenciária constituem fossos intransponíveis e verdadeiros obstáculos para os caminhos da liberdade.

Juntamente com o sursis e outros substitutos penais, o livramento condicional de um direito a constituir deve, efetivamente, cumprir a missão da pena num Estado social e democrático de direito, para que não se converta numa arma do Estado esgrimida contra a sociedade, trocando a sua eficácia pelo terror. Segundo a doutrina de Santiago Mir Puig ${ }^{32}$, a função social da pena consiste na criação de possibilidade de participação nos sistemas sociais, oferecendo alternativas à conduta delituosa. Para o penalista espanhol é esse o significado da função de ressocialização atribuída pelo direito positivo à execução das penas privativas de liberdade. Segundo ele, deve-se dar mais um passo em frente para que a chamada criação de possibilidades de participação seja resultado de um verdadeiro processo de interacão contínua entre o delinqüente e o Estado: aquele não deve ser tratado como puro objeto de um processo de 'condução' do Estado social, mas, na verdade, como o sujeito de um processo de regulação e aprendizagem. E tal processo deve visar não apenas a adaptação do sujeito às normas dominantes, mas, também a elaborar num processo de interação as alternativas ao comportamento criminoso e, com isso, a participação nas relações da vida social.

\section{Notas}

1. Conferência pronunciada em 8 de abril de 1983 no I Ciclo de Estudos de Direitos e Processo Penal patrocinado pelo Instituto dos Advogados Brasileiros - Rio de Janeiro.

2. O assunto tem motivado trabalhos específicos como a publicaçăo da UNESCO, The mass media in a violent world, 1971, e o relatório do Comitê Nacional de Prevenção da Violência, Prevénir la violence. Paris, 1980. A propaganda da violência foi apropriadamente avaliada por Técio Lins e Silva e Carlos Alberto Luppi. A cidade está com medo. Rio de Janeiro, 1982. p. 16 e ass.; 114 e ss. 
3. SARTRE, Jean-Paul. O existencialismo é um humanismo. Trad. de Vergilio Ferreira. Lisboa, 1978. p. 222.

4. DOTTI, René Ariel. Bases e alternativas para o sistema de penas. Curitiba, 1980. p. 407.

5. A propósito da crítica das penas acessórias e a deficiência do ordenamento atual, principalmente quanto à perda de função pública e a publicação de sentença, DOTTI, René Ariel, obra citada., p. 363 e ss.

6. A comissão elaboradora foi composta por Francisco de Assis Toledo (coordenador), Francisco de Assis Serrano Neves, Ricardo Antunes Andreucci, Miguel Reale Júnior, Hélio Fonseca, Rogério Lauria Tucci, René Ariel Dotti, e teve a valiosa contribuição de Sérgio Marcos de Moraes Pitombo.

7. A comissão revisora do Anteprojeto de Reforma da parte geral do Código penal foi integrada por Francisco de Assis Toledo, Miguel Júnior e Jair Leonardo Lopes.

8. Penas restritivas. Ciência penal. 1, 1981, p.78.

9. SARTRE, Jean-Paul. Obra citada, p. 241.

10. Analisando essa corrente crítica, ANGEL, Marc. La sospensione dell'esecuzione della sentenza. Milão, 1976, p. 80 e ss.; GARCIA, Basileu, Instituicões de direito penal. São Paulo, s.d. V.I. t. 2, p. 540. TUCCI, Rogério Lauria, Persecução penal, prisão e liberdade. São Paulo, 1980, p. 300.

11. MENDES, José. Da condenaçăo condicional. Revista de Direito. 1909. 12: $258-9$.

12. BRUNO, Anibal. Direito penal. Rio de Janeiro, 1967, T. 3, p. 169.

13. BRUNO, Anibal. Obra citada, p. 169.

14. JESCHECK, Hans-Heinrich. Tratado de derecho penal. Trad de Mir Puig e Muñoz Conde, Barcelona, 1981. V. 2, p. 1.153.

15. JESCHECK, Hans-Heinrich, ob. e loc. cit., nota n: 1.

16. Exposicão de motivos ao Código penal português, n: 11.

17. JESCHECK, Hans-Heinrich, ob. e loc. cit.

18. O Supremo Tribunal Federal, reiteradamente, vem entendendo que o sursis é um direito do réu desde que satisfeitos os requisitos legais (RTJ 42/722 e DJU de 5.6.1981, p. 5.396). 1981). Especi- ficamente sobre o tema, Celso Delmanto: Dos direitos públicos subjetivos do réu no Código penal, in Anais do I Congresso Brasileiro de Política Criminal e Penitenciária. Brasília, 1981, no prelo.

19. A propósito do tema, Alípio Silveira, O sursis em regime de prova. São Paulo, 1975. p. 43 e ss.

20. Conceituando o sursis como medida penal de caráter sancionatório, preferimos utilizar o emprego de vocábulos como aplicar, impor, etc., e não conceder ou deferir o chamado 'benefício'. Assim, a suspensão condicional é aplicada, imposta etc.

21. Para um confronto entre o Código penal de 1940 e as reformas introduzidas pela lei $n^{\circ}$ 416/77, relativamente ao sursis, ver Damásio de Jesus. O novo sistema penal. São Paulo, 1977. p. 97 e ss.; e Rogério Lauria Tucci. Aspectos procesśuais da reforma penal de 1977, in Revista dos Tribunais. (506): 309.

22. Os artigos 77, II; 81 e seu parágrafo segundo utilizam as expressőes benefício e beneficiário.

23. A comissão elaboradora do Anteprojeto da Lei de Execucão Pe nal foi composta por Francisco de Assis Toledo (coordenador), René Ariel Dotti, Benjamim Morais Fllho, Miguel Reale Júnior, Rogério Lauria Tucci, Ricardo Antunes Andreucci, Sérgio Marcos Moraes Pitombo e Negi Calixto. A comissão revisora foi composta por Francisco de Assis Toledo, René Ariel Dotti, Jason Soares Albergaria, Ricardo Antunes Andreuccie recebeu importante contribuição de Sérgio Marcos de Moraes Pitombo e Everardo da Cunha Luna.

24. Sanç̃es penais. Trad. de Sérgio Fragoso, Rio de Janeiro, 1970, p. 132,133 .

25. Instituições de direito penal. São Paulo, sd. v.1. t.2, p. 559 e 560.

26. Op. e v. cit., p. 1166.

27. Op e t. cit., p. 178.

28. TUCCl, Rogério Lauria. Aspectos processuais da Reforma penal de 1977. In Revista dos Tribunais. p. 310.

29. Diário do Congresso Nacional. 4. 6. 1976, p. 8.

30. Traité de droit pénal et criminologie. Paris, 1969. p. 510.

31. Os incidentes da execução da pena são as conversões, o excesso ou desvio, a anistia e o indulto (arts. 179 e 192).

32. Introducción a las bases del derecho penal, Barcelona, 1976. p. 85,86 . 